\title{
Using an Online Interactive Game to Enhance the Learning Outcomes for First Year Tertiary Students
}

\author{
Susan Salter ${ }^{1 *}$, Jane Pittaway ${ }^{1}$, Karen Swabey ${ }^{2}$, Mike Capstick ${ }^{1}$, Tracy Douglas ${ }^{1}$ \\ ${ }^{1}$ School of Human Life Sciences, University of Tasmania, Launceston, Australia \\ ${ }^{2}$ School of Education, University of Tasmania, Launceston, Australia \\ Email: *Susan.Salter@utas.edu.au
}

Received August 31 ${ }^{\text {st }}$ 2012; revised September 29 ${ }^{\text {th }}$, 2012; accepted October $12^{\text {th }}, 2012$

\begin{abstract}
Academics acknowledge that students are often unable to link and extend first year, first semester foundation material throughout their undergraduate degree. The use of a pedagogically sound interactive digital game-based learning (DGBL) resource to engage first year biological science students in recalling, linking and applying foundation knowledge and increasing their learning outcomes has been explored. According to the current literature there exists no evidence that DGBL resources have previously been used to address this transfer and linking of knowledge and core skills. Results from our study of student perceptions and student learning outcomes suggest that our creatively designed resource has effectively targeted a mixed cohort of students to retain, link and extend foundation knowledge. Our study also indicates that DGBL resources have a valid role in enabling students, many of whom are classed as "digital natives”, to demonstrate positive learning outcomes by successfully recalling and transferring unit content into new learning domains.
\end{abstract}

Keywords: Interactive Game; Learning Outcomes; Tertiary; Life Sciences; Creative Design

\section{Introduction}

Foundation knowledge is a major component of first year unit content at university level and is the platform for developing and expanding learning in successive units, particularly in specific, discipline based, professional degrees. Traditional presentation methods (i.e., lecture formats) are particularly disengaging for today's students, tending to produce "uninterested pragmatists who cram for tests, commit the material to shortterm memory, and quickly forget it thereafter” (Foreman, 2003: p. 62). As a result, academics and educational developers have embraced technology to develop creative and complementary alternative learning resources to provide a blended learning approach. We have developed a web-based multi-player interactive game fulfilling the pedagogical criteria of DGBL. This resource enables students to recall foundation material from core units and to transfer and link knowledge and concepts, while engaging in a fun and stimulating learning environment. The purpose of this paper is to share the results from the use of a DGBL resource aimed at supporting the recall of foundation knowledge and the transfer of that knowledge to similar learning constructs. The effect of this creative resource on student learning outcomes is also explored.

\section{Digital Game-Based Learning (DGBL)}

DGBL is defined as "any marriage of educational content and computer games” (Prensky, 2001a: p. 145) and is an ideal platform to engage first year student learning. DGBL resources have been available for a number of years but have increased in complexity and diversity since Web 2.0 applications became available post year 2000 (Alexander, 2006; Cheung, Yip,

${ }^{*}$ Corresponding author.
Townsend, \& Scotch, 2008; Geith, 2008; Greenhow, Robelia, \& Hughes, 2009; Jones, Ramanau, Cross, \& Healing, 2009; Owston, 2009). There is also an increased expectation among the current student population for sophistication in DGBL which is based on their individual experiences of technology use.

The inclusion and alignment of both game taxonomy and learning taxonomy (Van Eck, 2006b) in a resource has a profound influence on successful engagement and learning outcome. Our DGBL resource has been constructed using a teaching methodology which includes a constructivist approach to knowledge transfer (Macaulay \& Cree, 1999) and a spiral curriculum involving iterative processes of scaffolding (Kiili, 2007). In addition, one of the primary indications of successful game design is its ability to elicit emotional enjoyment in the player-i.e., if the game isn't fun, it won't be played or revisited (Prensky, 2001a; Sandford \& Williamson, 2005). Humans who become overwhelmingly engaged in an activity are described as "in the zone", or experiencing "flow". Flow is a model of emotional experience which is so gratifying, that people are willing to do it for its own sake (Csikszentmihalyi, Abuhamdeh, \& Nakamura, 2005). Our DGBL resource integrates the essential game design elements required to maintain such immersion whilst generating learning outcomes. It also includes essential elements designed by Pivec \& Kearney (2007), such as persistent re-engagement, player control, scaffolding of abilities, different learning types (e.g., skills-based, knowledgebased, effective), cognitive challenge and reflection.

\section{Immersing DGBL into the First Year Curriculum}

"Digital natives" is a term which refers to the new generation of students, predicated around their exposure to, and use of, 
recent modern technologies (Prensky, 2001a; Van Eck, 2006b; Kennedy, Judd, Churchward, \& Gray, 2008). First year cohorts contain a large number of "digital natives" who expect the incorporation of sophisticated digital technology as a component of their learning resources. An intrinsic shift in cerebral information processing mechanisms has occurred for "digital natives" (Prensky, 2005), compared with those adopting this technology later in life. Prensky (2005) suggests that "digital natives" brains respond in a different manner to education methodology and content by processing information at a different speed (twitch speed), and thus require information to be presented in a non-traditional manner to optimize learning. This is supported by some researchers (Van Eck, 2006a; Oblinger \& Oblinger, 2005) and not by others (Kennedy, Judd, Churchward, \& Gray, 2008). As a result of this, the needs of "digital natives" and other students must be considered by all staff involved in first year teaching and learning. Many staff are already engaging with digital teaching resources and a survey conducted in 2005 to explore educators' attitudes to digital games in the classroom showed that the majority of United Kingdom teachers were open-minded about their usefulness (Futurelab, 2006).

One of the goals of DGBL is to allow students to enter the game environment at their own level of expertise, and provide the means (scaffolding) for them to develop mastery by linking and integrating the knowledge gained. Scaffolding, in pedagogical terms, refers to the different kinds and amounts of support that a learner receives during the process of acquiring knowledge, and allows learners to "perform activities that they were unable to perform without this support" (Merrienboer, Clark, \& Croock, 2002: p. 54). The support, in the form of interventions, can be through the educators (e.g., teacher, tutor) or by other means such as assistance mechanisms built into digital learning resources (e.g., feedback, just-in-time help).

Digital games whose structures are competitive, utilize content information as currency (or a weapon) in gaming contexts, to motivate and encourage players to battle for intellectual supremacy (Herz, 2002). Motivation, when applied to learning systems, is defined as "the process by which we consciously or unconsciously allocate working memory resources” (Brooks \& Shell, 2006: p. 17). Motivation leads to student engagement which is of paramount importance in any effective learning strategy.

\section{The Game Project}

There is a general assumption that skills and knowledge developed in first year will be transferable to other academic contexts and real life situations, but, students are often unable to identify these links and apply their skills and knowledge into new domains (Britton et al., 2005; Scott, 2005; Rebello et al., 2007). The transfer of core skills can occur under particular learning conditions supported and enhanced by curriculum design and specific pedagogical objectives (Justice, Rice, \& Warry, 2009; Lobato, 2008). The game project involved the development and implementation of an online interactive game (Alien Tissue II) to enable students to link content between successive units in the first year of their degrees. The methodology of the online game allows for a structured progression by linking and extending foundation knowledge with the increasing complexity of the curriculum content. Currently there exists no literature on the use of DGBL resources to link and extend this foundation knowledge and/or to produce positive learning outcomes.

Students studying Health Science based degrees (including Exercise Science, Biomedical Science, and Environmental Health) and, some Education and Science degrees, study a Cell Biology unit in semester one. This unit is a prerequisite for the semester two units, Anatomy \& Physiology 1 and Microbiology and Health. The online game incorporates content from the above units in a tiered game system to engage students in both learning and retaining the unit material, and in recognizing and applying cross-unit content. The game is interspersed progressively with the introduction of new and more challenging concepts, thus allowing the combination of experiential and problem based learning methodology to create a balance between student boredom and student challenge, motivation and engagement. Alien Tissue II also includes a suite of single player games (Appendix 1) designed for students to use for quick revision.

The game is currently written using a combination of perl, html and java script and is compliant for students with disabilities who use Dragon or Jaws software for computer access. The content of each specific unit (i.e., Cell Biology, Anatomy \& Physiology 1 and Microbiology \& Health) is delivered in the game using multiple choice questions (MCQ). The MCQ's are written at differing orders of difficulty based around the domains of Bloom's taxonomy of learning (Bloom \& Krathwohl, 1956). This taxonomy is a framework for organizing learning objectives related to curriculum development and assessment. The content of the MCQ's in the game varies from simple knowledge recall from the long term memory, to combinations of recall and/or application and/or analysis, evaluation and synthesis requiring both short and long term memory. Research suggests that the MCQ format, when written according to the higher levels of Bloom's taxonomy, offers comparable reliability and learning outcomes to the short answer format (Bacon, 2003; Selby, Blazey, \& Quilter, 2008; Zheng, Lawhorn, Lumley, \& Freeman, 2008).

Feedback is available for the majority of the questions in the game. The content of the foundation MCQ's is linked to similar, but more complex content areas throughout the first year units. This linking, forms part of the feedback as the student progresses through related curriculum content. The feedback is designed as a help system (scaffolding).and is provided after an answer to an individual question. A study by Sweetser and Dennis (2003) involving first year psychology students, demonstrated that computer games used as a learning resource are improved by the "addition of a help system that provides information to the user at the time that it is most required" (p. 49).

The game is designed to reward students for demonstrating and applying knowledge. The rewards increase in value according to the difficulty, application and linking of the conceptual knowledge which is required to correctly answer individual questions. There is a reward system for certainty of using a correct answer and the rewards are embedded in specific scenarios-Appendix 2 for an example of a student playing Alien Tissue II. In Cell Biology and Anatomy \& Physiology 1, the scenario involves the prevention of mutation in cell lines. In Microbiology \& Health, the scenario is thwarting an invasion by an alien microbe. The rewards include ATP (a form of energy currency), immune cells, enzyme levels and mutation resistance. These rewards increase the strength of the player against attack from another player, which is one of the interactive components of the game. 


\section{Method}

\section{Questionnaire}

A hard copy anonymous questionnaire, containing both closed and open-ended questions, was used to survey the use of the game by students enrolled in Anatomy \& Physiology 1. Of the 25 questions in the questionnaire, the results of nine closed and two open-ended questions are presented and discussed. Ethics approval for this questionnaire was granted by the Tasmanian Health and Medical Human Research Ethics Committee (application number HOO10216).

\section{Introduction of the Game to the Students}

Students in Anatomy \& Physiology 1 were introduced to the game in dedicated computer laboratory sessions in the second week of semester two. All students had completed a Cell Biology unit at UTas in semester one of the first year of their undergraduate degree.

\section{Study Sample Demographics and Data Collection}

First year students enrolled in Anatomy \& Physiology 1 on the Launceston campus of the University of Tasmania (UTas) were asked to complete a questionnaire during tutorial time in the thirteenth week of semester two. The cohort comprised 311 students (154 males, 157 females) enrolled in the first year of a UTas undergraduate degree in the Faculty of Health Science, Faculty of Education, Faculty of Business or Faculty of Science, Engineering and Technology. Students gave their informed consent and all responses were anonymous. The students were a varied cohort, representing ten different degree courses. The cohort comprised a mixture of Grade 12 school leavers, mature aged students and students from interstate and overseas. The overseas students comprised approx. $7.5 \%$ of the cohort. The age range was 18 to 64 years with an average age of 22 years. Only $18 \%$ of the cohort were 25 years of age or older.

The questions were designed to obtain a variety of information: general demographic data; general computer use; frequency of game access; opinion regarding the use of a digital game as a learning tool; perceptions of knowledge recall from Cell Biology; and perception of transfer of learning across three core first year modules, Cell Biology, Anatomy \& Physiology 1, and Microbiology \& Health. The eleven specific questions used to gather responses for this study are displayed in Table 1.

Students' perceptions of knowledge recall and transfer of learning were obtained via guided, closed questions within the questionnaire (Table 1). Transfer of learning was not quantitatively measured because controversy remains regarding the methodology used to gather such information, and in fact, about what parameters are actually being measured (Barnett \& Ceci, 2002; De Corte, 2007; Lobato, 2006; Rebello et al., 2007).

\section{Results and Discussion}

Results from this study were evaluated using a qualitative research methodology including descriptive statistics and phenomenology. Data regarding gender and degree were collated according to commonality of response and presented as rudimentary summations about the sample cohort and their respective responses. Some of the interpretations are subjective in nature, particularly those based around the open-ended questions. Whilst phenomenology usually relies on in-depth interns
Table 1.

Questions analyzed in this study ${ }^{\mathrm{a}}$.

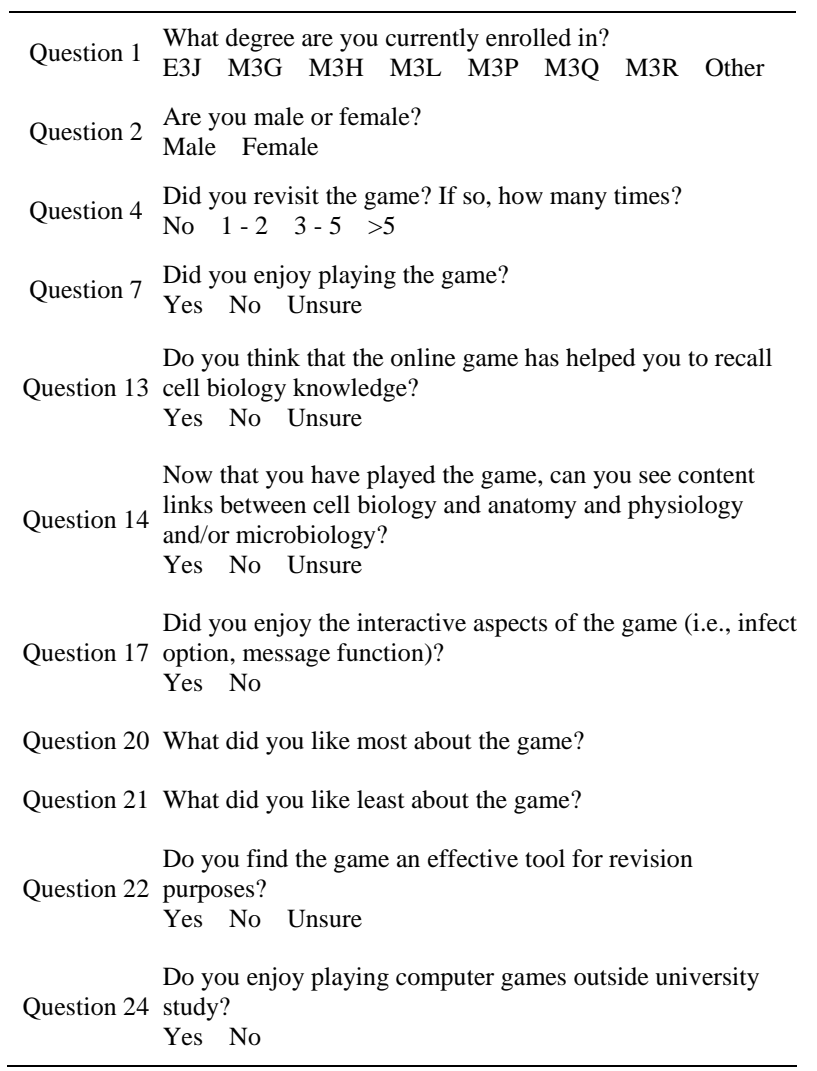

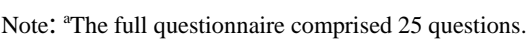

(Hansen, 2006). This study evaluated results from 161 respondents. The overall mean age of the total cohort (311 students) was 22 years. This suggests that the game effectively targeted the "digital natives" (Van Eck, 2006c) within our student cohort.

\section{Student Feedback on the Game}

One of the aspects of this study was to determine if the students themselves could identify whether or not the game assisted them with foundation knowledge recall and making links between unit material and concepts. Results of the closed questions (questions $13 \& 14$ ) revealed that a majority (77\%) of the respondents recognized that the game had improved their ability to recall foundation knowledge and to use it in a related context. The directed nature of the questions did not seem to influence the students' responses because answers to the open-ended question about what respondents most liked about the game (question 20), supported their answers to questions 13 and 14. For example, one respondent agreed the game had helped with recall and making the links between units and commented the game was "More than just regurgitating information". Another respondent on the other hand, thought the game helped make the links between units but didn't help with content recall. These answers corresponded with his opinion that the game "helps relate cell bio to anat \& physic". A small number of respondents $(n=9)$ thought the game was useful for Cell Biology content recall but were either unsure if it helped make content links, or thought that it didn't. These respondents 
all commented that the game either helped with revision or to recall Cell Biology content.

\section{Impact on Student Learning Outcomes}

At present, the conventional measure of transfer of learning, is the students' ability to be successful in their assessments and ultimately to graduate from university. The result of this study suggests that the DGBL increases knowledge recall and transfer of learning in Anatomy \& Physiology 1. Student learning outcomes were enhanced in the unit when the DGBL was available as a learning resource, as shown by end of semester examination results. The average theory exam result was $52.3 \%$ when the resource was available, compared to $48.3 \%$ in the year prior to its implementation. It was also noted that an average theory exam result of above $50 \%$ was recorded for this unit when the DGBL was available. This had not been observed in previous years. The theory exam contains both MCQ and Short Answer questions (SA). In comparing MCQ and SA sections; there was an improvement in the MCQ section compared to the SA section of the theory exam. When the DGBL was available, students averaged $62.8 \%$ in the MCQ section compared to $57.7 \%$ in the previous year. However, only a slight improvement was observed in the SA section (48.2\% with the DGBL, compared to $46.9 \%$ without the DGBL). As the DGBL is MCQ based, it is apparent that it assists knowledge recall in this form of summative examination and one respondent stated that they liked the game because it "was handy for revising for multiple choice questions".

These increases in students' examination scores also need to be considered in the context of this specific student cohort and any other pedagogical methodologies and platforms changed within the unit, such as the incorporation of Peer Assisted Study Sessions (PASS), which were also introduced into Anatomy \& Physiology 1. Further analysis of the student cohort performance still needs to be compared across all first year units to determine if there are other factors involved in the improvement of their learning outcomes.

One of the aspects of this study was to determine if the students themselves could identify whether or not the game assisted them with foundation knowledge recall and making links between unit material and concepts. 75\% of respondents found that the game helped them recall cell biology knowledge whilst $70 \%$ agreed that it enabled them to identify content links between related units of study. This was also supported by the students' responses to the open-ended questions about what they most liked about the game. For example, one respondent liked the game because the "game helped me to recall things done in past units and link them to the present ones". Similarly another respondent found that the game “... reinforced material learnt”. Furthermore, questionnaire responses indicated that the resource did have a positive impact on student learning as one respondent liked the game because it "helped work out what I did and didn't know", while another respondent stated that "it helped to recall info and enforce (sic) confidence in knowledge of material". Similarly, another respondent found the game to be "a different/motivating way of learning and with the implementation of the hint-help-I learnt a lot". These responses indicated that the DGBL has a positive impact on student learning.

Whether or not respondents played other computer games did not seem to influence their enjoyment of this game. In fact,
$89 \%$ of respondents indicated that they enjoyed the game even though only $49 \%$ enjoyed playing computer games outside of their university studies. Respondents liked the game because it was "fun and interactive" and "it was a fun way of learning". One respondent also stated that "it provided learning in an enjoyable environment, learning by playing a game”. The game also incorporated some interactive components to engage students and $81 \%$ of respondents enjoyed the interactiveness of the game. This seemed to be reflected by the gender of the individual as male respondents were fairly consistent about liking the game and enjoying playing other computer games. The female respondents however, admitted to enjoying the game to a greater degree than would be expected, considering the very small proportion who normally played other computer games. Female players typically liked the game because "it was fun and educational at the same time". They were able to "gain knowledge in an enjoyable way" and "being able to infect other players and build resistance" was also favored by some of the female players.

These results suggest the format of the game was such that it not only maintained the interest of habitual computer game users (mainly male in this instance) and engaged student learning but, it also succeeded in capturing the interest of those students (mainly female in this study) less inclined to engage in game playing. Gender is an issue in DGBL, as to whether digital games are a "boy toy" or, indeed, if females will use them to the same degree (Prensky, 2001b). In addressing the issue of whether males and females may prefer differently styled games, it is suggested that whilst some females might prefer "interaction" rather than "action”, that fundamentally, "an exciting game is an exciting game", and gender is not an issue if the games are engaging and enjoyable (Prensky, 2001b). Paraskeva, Mysirlaki and Papagianni (2010), in discussing the development of educational multi-layer online games, states that "females enjoy games with characteristics which they consider to be fun, such as games played against the computer, puzzles and quiz games” (p. 500).

\section{Summary of Findings and Future Directions}

The outcomes which support student use of a game format include emotional engagement, motivation, challenge and a feedback scaffolding system. The results of this study, contribute significantly to the body of literature about the use of digital game resources for transfer and application of foundation knowledge, particularly at the level of the first year tertiary experience. The game has succeeded in engaging and motivating both "digital natives" and those new to game technology, enabling them to acquire and transfer knowledge with positive learning outcomes. We acknowledge that this study worked within a relatively defined cohort of students in terms of social and academic environment. Future studies encompassing a more diverse student sample should support and strengthen the validity of these findings and permit extrapolation to a wider cohort.

Currently the game supports teaching and learning in three first year units (Cell Biology, Anatomy, \& Physiology 1, Microbiology) which are common to a number of Health Science undergraduate degrees. Development of the game to include support for three additional units is currently underway, with funding being sought to develop this. It is envisaged that ultimately the game will be developed sequentially to include 
modules which support and link second and third year undergraduate units, particularly in the Faculties of Health Science and Education. The resource also has the potential to be expanded into a generic game based tool for interdisciplinary use across faculties. However, Van Eck (2006c: p. 18), cautions against arguing that "all games are good for all learners and for all learning outcomes". He emphasizes that research is needed into understanding "why DGBL is engaging and effective" and the importance of taking a realistic direction for "when, with whom, and under what conditions", digital games can be successfully incorporated into "the learning process to maximize learning potential”. In addition, Krotoski (2005) believes that whilst today's students are accepting digital games as a powerful learning tool, it may be a challenge to convince the educators who do not yet embrace this technology.

\section{Conclusion}

Ultimately, the progressive transfer of foundation knowledge between units, and its application in more complex contexts, is the aim of all higher education institutions. Based on the results of our study which used a DGBL resource in first year units, there are indications of positive learning outcomes in students' recall, application and transfer of knowledge. A digital game based resource, which is creatively designed to engage and motivate students whilst simultaneously increasing their learning outcomes, is a valid and valuable tool in the portfolio of teaching and learning resources, particularly at the first year level.

\section{Acknowledgements}

The authors would like to acknowledge the University of Tasmania for funding this project.

\section{REFERENCES}

Alexander, B. (2006). Web 2.0: A new wave of innovation for teaching and learning? Educause Review, 41, 32-44. https://www.middlebury.edu/NR/rdonlyres/2C9EFFFC-00B4-46E99CE5-32D63A0FE9B5/0/UNBOUND_02_02_Web2.pdf

Barnett, S. M., \& Ceci, S. J. (2002). When and where do we apply what we learn? A taxonomy for far transfer. Psychological Bulletin, 128, 612-637. doi:10.1037/0033-2909.128.4.612

Bacon, D. (2003). A comparison of multiple-choice and short-Answer questions in a marketing context. Journal of Marketing Education, 25, 31-36. doi: $10.1177 / 0273475302250570$

Bloom, B., \& Krathwohl, D. (1956). Taxonomy of educational objectives: The classification of educational goals, by a committee of college and university examiners. Handbook 1: Cognitive domain. New York: Longmans.

Britton, S., New, P. B., Sharma, M. D., \& Yardley, D. (2005). A case study of the transfer of mathematics skills by university students. International Journal of Mathematical Education in Science and Technology, 36, 1-13. doi:10.1080/00207390412331271401

Brooks, D., \& Shell, D. (2006). Working memory, motivation, and teacher-initiated learning. Journal of Science Education and Technology, 15, 17-30. doi:10.1007/s10956-006-0353-0

Cheung, K., Yip, Y., Townsend, J., \& Scotch, M. (2008). (HCLS) Health care and life sciences data mashup using Web 2.0/3.0. Journal of Biomedical Informatics, 41, 694-705. doi:10.1016/j.jbi.2008.04.001

Csikszentmihalyi, M., Abuhamdeh, S., \& Nakamura, J. (2005). Flow. In A. Elliot, \& C. Dweck (Eds.), Handbook of competence and motivation (pp. 598-608). New York: Guilford.

Foreman, J. (2003). Next generation: Educational technology versus the lecture. Educause Review, 38, 13-22.

Futurelab (2006). Close to $60 \%$ of UK teachers want computer games in the classroom. URL (last checked 11 May 2009). http://www.future.org.uk/about_us/Press_Release184

Geith, C. (2008). Teaching and learning unleashed with web 2.0 and open educational resources. URL (last checked 21 October 2009). http://net.educause.edu/ir/library/pdf/PUB7202v.pdf

Greenhow, C., Robelia, B., \& Hughes, J. (2009). Learning, teaching, scholarship in a digital age: Web 2.0 and classroom research: What path should we take now? Educational Researcher, 38, 246-259. doi:10.3102/0013189X09336671

Hansen, E. C. (2006). Successful qualitative health research: A practical introduction. Crows Nest, New South Wales: Allen \& Unwin.

Herz, J. (2002). Gaming the system: What higher education can learn from multiplayer online worlds. In M. Devlin, R. Larson, \& J. Meyerson (Eds.), The internet and the university: Forum 2001 (pp. 169-191). Boulder, CO: Educause. http://www.educause.edu/ir/library/pdf/ffpiu019.pdf

Jones, C., Ramanau, R., Cross, S., \& Healing, G. (2009). Net generation or digital natives: Is there a distinct new generation entering university? URL (last checked 21 October 2009).

http://www.sciencedirect.com/science?_ob=MImg\&_imagekey=B6V CJ-4XFXSPS-2-4\&_cdi=5956\&_user $=1526876 \&$ \& pii $=$ S0360131509 002620\&_orig=search\&_coverDate $=04 \% 2 F 30 \% 2 F 2010 \&$ \&k $=9994$ 59996\&view $=$ c\&wchp $=$ dGLzVzz-zSkzk\&md5=41d1d800d15a15bd 2583a5ec3bea8cd6\&ie=/sdarticle.pdf

Justice, C., Rice, J., \& Warry, W. (2009). Developing useful and transferable skills: Course design to prepare students for a life of learning. International Journal for the Scholarship of Teaching and Learning, 3, 1-19.

Kennedy, G., Judd, A., Churchward, A., \& Gray, K. (2008). First year students' experiences with technology: Are they really digital natives? Australasian Journal of Educational Technology, 24, 108-122.

Kiili, K. (2007). Foundation for problem-based gaming. British Journal of Educational Technology, 38, 394-404. doi:10.1111/j.1467-8535.2007.00704.x

Krotoski, A. (2005). Games for learning. URL (last checked 11 May 2009).

http://www.technologyreview.com/printer_friendly_article.aspx?id= 14

Lobato, J. (2006). Transfer strand: Alternative perspective on the transfer of learning: History, issues, and challenges for future research. Journal of the Learning Sciences, 15, 431-449. doi:10.1207/s15327809jls1504_1

Macaulay, C., \& Cree, V. E. (1999). Transfer of learning: Concept and process. Social Work Education, 18, 183-194. doi:10.1080/02615479911220181

Merrienboer, van J., Clark, R., \& Croock, M. (2002). Blueprints for complex learning: The 4C/ID-model. Educational Technology, Research and Development, 50, 2.

Oblinger, D., \& Oblinger, J. (2005). Educating the Net Generation. URL (last checked 12 December 2008). www.educause.edu/educatingthenetgen

Owston, R. (2009). Digital immersion, teacher learning, and games. Educational Researcher, 38, 270-273. doi:10.3102/0013189X09336673

Paraskeva, F., Mysirlaki, S., \& Papagianni, A. (2010). Multiplayer online games as educational tools: Facing new challenges in learning. Computers \& Education, 54, 498-505. doi:10.1016/j.compedu.2009.09.001

Pivec, M., \& Kearney, P. (2007). Games for learning and learning from games. Organizacija, 40, 267-272.

Prensky, M. (2001a). Do they really think differently? On the Horizon, 96, 7-15.

Prensky, M. (2001b). Digital game-based learning. New York: McGraw-Hill.

Prensky, M. (2005). Digital natives, digital immigrants. Gifted, 135, 29-31.

Rebello N. S., Cui, L., Bennett, A. G., Zollman, D. A., \& Ozimek, D. J. (2007). Transfer of learning in problem solving in the context of mathematics \& physics. In D. Jonassen (Ed.), Learning to solve com- 
plex scientific problems (pp. 223-246). Mahwah, NJ: Lawrence Earlbaum.

Sandford, R., \& Williamson, B. (2005). Games and Learning. URL (last checked 21 February 2010).

http://steinerweb.org.uk/pdf/games_and_learning.pdf

Scott, J. (2005). Students' perceptions of skills acquisition in the undergraduate bioscience curriculum. URL (last checked 21 January 2008).

http://www.bioscience.heacademy/journal/vol6/beej-6-1.pdf

Selby, J., Blazey, P., \& Quilter, M. (2008). The relevance of multiple-choice assessment in large cohort business law units. Australian Law Teachers' Law Journal, 1, 203-212.

Sweetser, P., \& Dennis, S. (2003). Facilitating learning in a real-time strategy computer game. In R. Nakatsu, \& J. Hoshino (Eds.), Entertainment computing: Technologies and applications. International Workshop on Entertainment Computing (pp. 49-56). Boston, MA:
Kluwer.

Van Eck, R. (2006a). Learning through gaming: Why games in education and the workplace make sense. The annual meeting of the texas association of state systems for computing and communications. Corpus Christi, TX: Information Science

Van Eck, R. (2006b). Building artificially intelligent learning games. In D. Gibson, C. Aldrich, \& M. Prensky (Eds.), Games and simulations in online learning (pp. 1-72). Hershey, PA: Ideas Group. doi:10.4018/978-1-59904-304-3.ch014

Van Eck, R. (2006c). Digital game-based learning: It's not just the digital natives who are restless. Educause Review, 41, 16-30.

Zheng, A., Lawhorn, J., Lumley, T., \& Freeman, S. (2008). Application of Bloom's Taxonomy Debunks the "MCAT Myth". Science, 319, 414-415. doi:10.1126/science.1147852 
Appendix 1. Screen Capture of Alien Tissue II and Single Player Games Available at biosciencelink.com

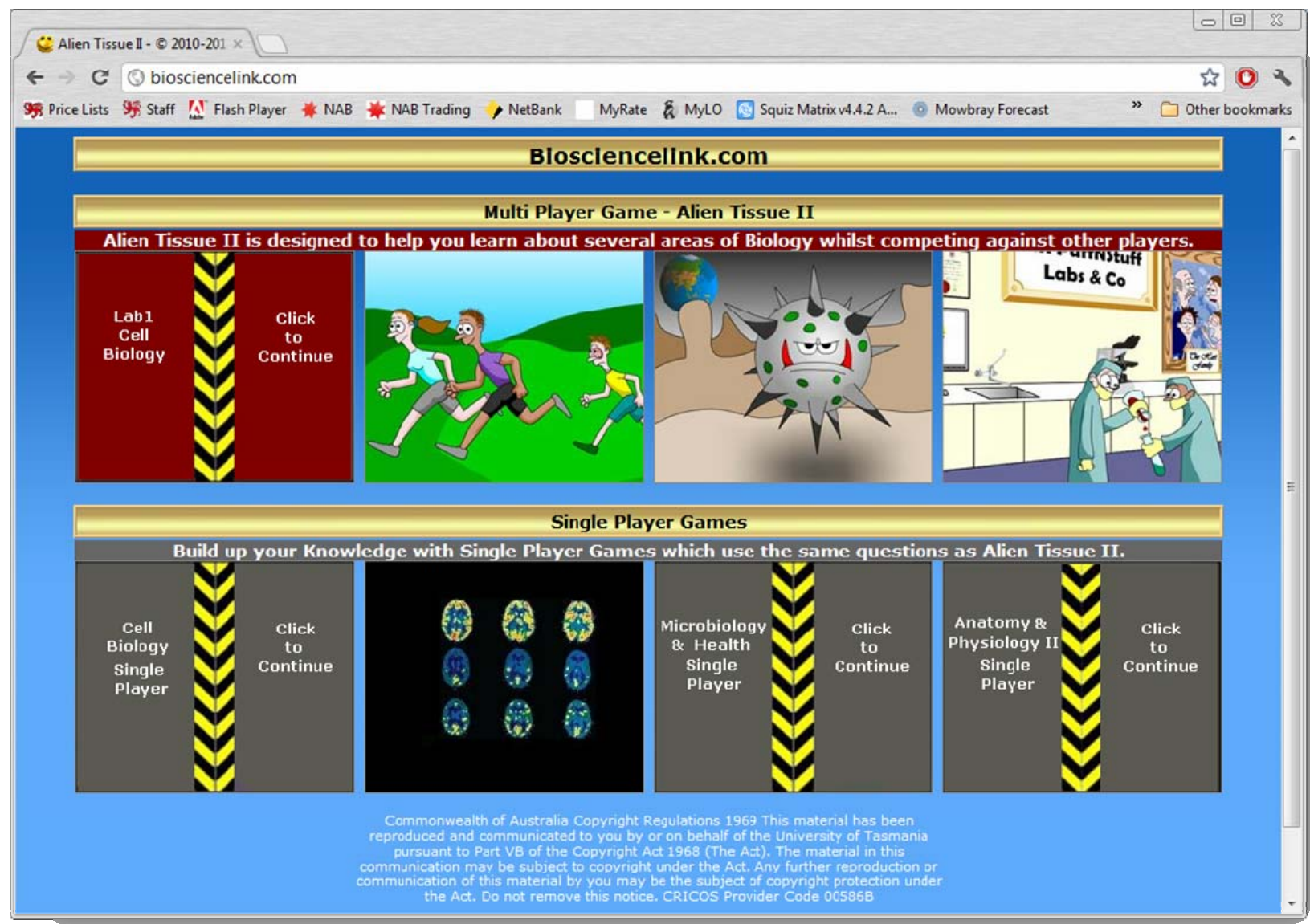




\section{Appendix 2: Example of a Student (Username: Golgi) Playing Alien Tissue II}

\section{Golgi logs onto game-selects Anatomy and Physiology 1 Lab}

Status: 120 ATP, Enzyme Levels: Average, Mutation resistance: Low, Immune cells: 11

\section{Click on Earn Credits, Quiz Credits Click on New Question:}

Q. 5) Which anatomical plane divides the body into equal left and right halves?
a) transverse
b) oblique
c) frontal
d) parasagittal
e) median

\section{Click on answer e) \\ Click on Certainty: High}

Correct.

Feedback: This plan is also referred to as the mid-sagittal plane.

12 ATP earned.

\section{Bank ATP}

Status: 132 ATP, Enzyme Levels: Average, Mutation resistance: Low, Immune cells: 11

\section{Click on Next Question}

Q. 39) Which of the following cell organelles would be most important to epithelial cells whose primary function is secretion?

a) Lysosomes

b) Peroxisomes

c) Golgi apparatus

d) Cilia

e) Desmosomes

Correct.

\section{Click on answer c) \\ Click on Certainty: Medium}

Feedback: Golgi apparatus package and process molecules into vesicles for export from the cell.

Links to the following Cell Biology Lab Questions:

CBQ 11) A hormone secreting cell would be expected to have a large number of:

Answer-Golgi apparatus and secretory vesicles distributed throughout its cytoplasm

CBQ 39) The functions of the Golgi apparatus include:

Answer-synthesis, storage, alteration and packaging

CBQ 118) Human pancreatic cells that are active in peptide hormone secretion would contain many: Answer-Golgi bodies

9 ATP earned.

\section{Bank ATP}

Status: 141 ATP, Enzyme Levels: Average, Mutation resistance: Low, Immune cells: 11

\section{Click on Next Question}

Q.152) The thick myofilaments in skeletal muscle are composed of the protein:
a) myosin
b) keratin
c) actin
d) troponin
e) tropomyosin

\section{Click on answer c)}

\section{Click on Certainty: Medium}

Incorrect. Correct answer is a)

Feedback: The myosin (thick) and actin (thin) myofilaments in individual sarcomeres enable a skeletal muscle to contract.

Links to the following Cell Biology Lab Question:

CBQ 8) Actin and myosin in muscle cells are best classified as:

Answer-movement proteins

-9 ATP earned.

Bank ATP.

Status: 132 ATP, Enzyme Levels: Average, Mutation resistance: Low, Immune cells: 11

\section{Click on Earn Credits \\ Click on Infect Credits \\ Select player to infect: Zeppity}

Report: You Lost

The results of your attack on Zeppity in Lab 2

Your attack strength was 54 units

Zeppity had a strength of 92 units

ATP lost: 34 ATP

Immune cells lost: 1

Immune cells destroyed: 1

Status: 98 ATP, Enzyme Levels: Average, Mutation resistance: Low, Immune cells: 10

\section{Click on Updates \\ Select Immune cells: 1 \\ (costs 50 ATP)}

Status: 48 ATP, Enzyme Levels: Average, Mutation resistance: Low, Immune cells: 11

\section{Click on Exit}

Select Exit Game and Logout 